\title{
PENERAPAN MODEL ARIMA UNTUK MEMPREDIKSI HARGA SAHAM PT. TELKOM Tbk.
}

\author{
Djoni Hatidja ${ }^{1)}$ \\ ${ }^{1)}$ Program Studi Matematika FMIPA Universitas Sam Ratulangi, Manado 95115 \\ e-mail: dhatidja@yahoo.com
}

\begin{abstract}
ABSTRAK
Penelitian ini bertujuan untuk mengetahui karakteristik data harga saham harian PT. Telkom, Tbk, membuat model dan melakukan prediksi harga saham PT. Telkom, Tbk bulan Mei sampai Juni tahun 2011. Data yang digunakan adalah data sekunder yang diambil dari website perusahaan PT. Telkom, Tbk sejak Januari 2010 sampai 30 Maret 2011 untuk memprediksi harga saham Mei sampai Juni 2011. Hasil penelitian menunjukkan bahwa model untuk harga saham maksimum adalah ARIMA $(3,1,3)$ dengan persamaan $\mathrm{Y}_{\mathrm{t}}=0.9648 \mathrm{Y}_{\mathrm{t}-1}+0.0133 \mathrm{Y}_{\mathrm{t}-2}+0.4662 \mathrm{Y}_{\mathrm{t}-3}$

$-0.4443 \mathrm{Y}_{\mathrm{t}-4}-0.006+0.1294 \varepsilon_{\mathrm{t}-1}-0.0441 \varepsilon_{\mathrm{t}-2}-0.5751 \varepsilon_{\mathrm{t}-3}$. Sedangkan model harga saham minimum adalah ARIMA $(3,1,1)$ dengan persamaan $\mathrm{Y}_{\mathrm{t}}=1.7504 \mathrm{Y}_{\mathrm{t}-1}-0.7347 \mathrm{Y}_{\mathrm{t}-2}-0.092 \mathrm{Y}_{\mathrm{t}-3}$ $+0.1077 \mathrm{Y}_{\mathrm{t}-4}+0.051-0.7275 \varepsilon_{\mathrm{t}-1}$. Prediksi harga saham maksimum dan minimum PT. Telkom, Tbk untuk bulan Mei sampai Juni didapatkan harga saham berkisar antara Rp. 7.099 sampai Rp. 7.282 .
\end{abstract}

Kata Kunci : ARIMA, PT. Telkom Tbk., Stasioner

\section{APPLICATION OF ARIMA TO FORECASTING STOCK PRICE OF PT. TELOKM Tbk.}

\begin{abstract}
The objevtives of this research was to knowed the daily stock price of PT. Telkom, Tbk, make models and predicted May up to June 2011 using the data from 2008 up to March 2011. Data that are used by secondary data and take from website of PT. Telkom, Tbk since January 2010 to March 2011 for predicting May to June 2011. The results showed that the maximum stock price model was ARIMA $(3,1,3)$ with $\mathrm{Y}_{\mathrm{t}}=0.9648 \mathrm{Y}_{\mathrm{t}-1}+0.0133 \mathrm{Y}_{\mathrm{t}-2}+0.4662 \mathrm{Y}_{\mathrm{t}-3}-0.4443 \mathrm{Y}_{\mathrm{t}-4}-$ $0.006+0.1294 \varepsilon_{\mathrm{t}-1}-0.0441 \varepsilon_{\mathrm{t}-2}-0.5751 \varepsilon_{\mathrm{t}-3}$. While the minimum stock price model was ARIMA $(3,1,1) \quad$ with $\quad \mathrm{Y}_{\mathrm{t}}=1.7504 \mathrm{Y}_{\mathrm{t}-1}-0.7347 \mathrm{Y}_{\mathrm{t}-2}-0.092 \mathrm{Y}_{\mathrm{t}-3}+0.1077 \mathrm{Y}_{\mathrm{t}-4}+0.051-0.7275 \varepsilon_{\mathrm{t}-1}$.
\end{abstract} Predicted maximum and minimum stock price of PT. Telkom Tbk. for May to June was Rp. 7.099 to Rp. 7.282 .

Keywords: ARIMA, PT. Telkom Tbk., stationary

\section{PENDAHULUAN}

\section{Latar Belakang}

PT. Telekomunikasi Indonesia, Tbk adalah perusahaan informasi dan komunikasi serta penyedia jasa dan jaringan telekomunikasi secara lengkap di Indonesia. PT. Telkom, Tbk merupakan salah satu BUMN yang sahamnya saat ini dimiliki oleh
Pemerintah Indonesia sebesar 52,74\% dan sisanya oleh publik.

Pada Tahun 2007 perekonomian dunia diguncang dengan adanya krisis ekonomi global yang dimulai dari negara adikuasa yaitu Amerika dan semakin dirasakan dampaknya pada tahun 2008. Sebagai bagian dari pelaku perekonomian dunia, Indonesia tidak terlepas dari pengaruh krisis global yang terjadi walaupun dengan presentase yang bervariasi (Ahmad, 2009). 
Pokok permasalahannya adalah para investor sangat tertarik dalam memiliki saham perusahaan dalam hal ini PT. Telekomunikasi Indonesia, Tbk untuk mengetahui lebih jelasnya kapan waktu yang cocok untuk membeli saham dan menjualnya kembali. Terlebih untuk PT. Telkom, Tbk sendiri yang merupakan penyedia jasa jaringan telekomunikasi terbesar di Indonesia dengan banyak kompetitor yang ada.

Kemampuan untuk memprediksi atau forecast merupakan salah satu teknik analisis yang bisa membantu para pelaku pasar modal untuk menentukan dasar pengambilan keputusan stategis yang bisa memberikan mereka keuntungan. Suatu pendugaan secara ilmiah terhadap masa depan akan jauh lebih berarti ketimbang pendugaan hanya mengandalkan intuisi saja.

Pada tahun 2009 Wongkar mencoba memprediksi saham PT. Telkom, Tbk tahun 2009 dengan data dari tahun 2001 sampai 2008 menggunakan data harga saham harian mingguan dengan metode Simple Exponential Smoothing. Dari latar belakang penelitian sebelumnya maka penulis mencoba memprediksi harga saham PT. Telkom, Tbk menggunakan metode ARIMA (Autoregressive Integrated Moving Average).

\section{Tujuan}

1. Mengetahui karakteristik data harga saham harian PT. Telkom, Tbk tahun 2008 sampai 2009

2. Membuat model dan melakukan prediksi harga saham PT. Telkom, Tbk bulan Mei sampai Juni tahun 2011 menggunakan data tahun 2008 sampai Maret 2011

\section{TINJAUAN PUSTAKA}

\section{ARIMA (Autoregressive Integrated Moving Average)}

Metode Autoregressive Integrated Moving Average (ARIMA) atau biasa disebut juga sebagai metode Box-Jenkins merupakan metode yang secara intensif dikembangkan oleh George Box dan Gwilym Jenkins pada tahun 1970 (Iriawan, 2006).

Kelompok model time series yang termasuk dalam metode ini antara lain: autoregressive (AR), moving average (MA), autoregressive-moving average (ARMA), dan autoregressive integrated moving average (ARIMA) (Razak, 2009).

\section{Model Autoregresif (Autoregressive, AR)}

Model Autoregresif (AR) pertama kali diperkenalkan oleh Yule pada tahun 1926 dan dikembangkan oleh Walker pada tahun 1931, model ini memiliki asumsi bahwa data periode sekarang dipengaruhi oleh data pada periode sebelumnya. Model Autoregresif dengan ordo $p$ disingkat $\operatorname{AR}(p)$ atau ARIMA $(p, 0,0)$ dan diformulasikan sebagai berikut (Halim, 2006) :

$$
\mathrm{Y}_{\mathrm{t}}=\mu+\phi_{1} \mathrm{Y}_{\mathrm{t}-1}+\phi_{2} \mathrm{Y}_{\mathrm{t}-2}+\ldots \ldots \ldots+\phi_{\mathrm{p}} \mathrm{Y}_{\mathrm{t}-\mathrm{p}}+\varepsilon_{\mathrm{t}}
$$

Dimana:

$\mathrm{M}=$ konstanta; $\phi_{1}, \ldots, \phi_{\mathrm{p}}$ :koefisien parameter autoregresif ke-p; $\mathrm{Y}_{\mathrm{t}-1}, \ldots, \mathrm{Y}_{\mathrm{t}-\mathrm{p}}:$ Variabel bebas; $\varepsilon_{t}$ :sisaan pada saat ke-t

\section{Model Rata-rata Bergerak (Moving Average, MA)}

Proses Moving Average berorde $\mathrm{q}$ menyatakan hubungan ketergantungan antara nilai pengamatan $Y_{t}$ dengan nilai-nilai kesalahan yang berurutan dari periode $t$ sampai t-q. (Sartono, 2006).

Model Moving Average (MA) pertama kali diperkenalkan oleh Slutzky pada tahun 1973, dengan orde $q$ ditulis MA $(q)$ atau ARIMA $(0,0, q)$ dikembangkan oleh Wadsworth pada tahun 1989 yang memiliki formulasi sebagai berkut (Halim, 2006).

$\mathrm{Y}_{\mathrm{t}}=\mu+\varepsilon_{\mathrm{t}}-\theta_{1} \varepsilon_{\mathrm{t}-1}-\theta_{2} \varepsilon_{\mathrm{t}-2}-. .-\theta_{\mathrm{p}} \varepsilon_{\mathrm{t}-\mathrm{q}}$

Dimana :

$\mathrm{M}=\quad$ konstanta; $\quad \theta_{1}, \ldots, \theta_{p}=$ koefisien parameter moving average ke-q; $\varepsilon_{t}=$ sisaan pada saat ke-t.

\section{Model ARMA (Autoregressive Moving Average)}

Model AR (p) dan MA $(q)$ dapat disatukan menjadi model yang dikenal dengan Autoregressive Moving Average (ARMA), sehingga memiliki asumsi bahwa data periode sekarang dipengaruhi oleh data pada periode sebelumnya dan nilai sisaan pada periode sebelumnya (Assauri, 1984).

Model ARMA dengan berorde $\mathrm{p}$ dan $\mathrm{q}$ ditulis ARMA $(p, q)$ atau ARIMA $(p, 0, q)$ 
yang memiliki formulasi sebagai berikut (Halim, 2006) :

$\mathrm{Y}_{\mathrm{t}}=\mu+\phi_{1} \mathrm{Y}_{\mathrm{t}-1}+. .+\phi_{\mathrm{p}} \mathrm{Y}_{\mathrm{t}-\mathrm{p}}+\varepsilon-\theta_{1} \varepsilon_{\mathrm{t}-1}-. .-\theta_{\mathrm{p}} \varepsilon_{\mathrm{t}-\mathrm{q}}$

Dimana:

$Y_{t}=$ Variabel tidak bebas; $\mu=$ konstanta; $\phi_{1}, \phi_{2}, \ldots, \phi_{\mathrm{p}}=$ Parameter $\quad$ Autoregresif;

$\theta_{1}, \theta_{2}, \ldots \ldots, \theta_{p}=$ koefisien parameter moving average; $\mathrm{Y}_{\mathrm{t}-1}, \mathrm{Y}_{\mathrm{t}-2}, \mathrm{Y}_{\mathrm{t}-\mathrm{p}}=$ Variabel bebas;

$\varepsilon_{t-q}=$ sisaan pada saat ke $\mathrm{t}-\mathrm{q}$

\section{Model ARIMA (Autoregressive Integrated Moving Average)}

Model AR, MA dan ARMA menggunakan asumsi bahwa data deret waktu yang dihasilkan sudah bersifat stasioner. Pada kenyataannya, data deret waktu lebih banyak bersifat tidak stasioner (Sadeq, 2008).

Jika data tidak stasioner maka metode yang digunakan untuk membuat data stasioner dilakukan adalah differencing untuk data yang tidak stasioner dalam rata-rata dan proses transformasi untuk data yang tidak stasioner dalam varian (Mulyana, 2004).

Bentuk umum model ARIMA dapat dinyatakan dalam persamaan berikut (Sartono, 2006):

$\Phi_{\mathrm{p}}(\mathrm{B}) \nabla^{\mathrm{d}} \mathrm{Y}_{\mathrm{t}}=\xi+\Theta_{\mathrm{q}}(\mathrm{B})$

Dimana :

$Y_{t}$ : Nilai pengamatan saat $\mathrm{t}$

$\Phi_{p}$ : Parameter autoregresif (Autoregressive)

$\mathrm{B}$ : Operator geser mundur

d : Parameter pembedaan (differencing)

$\xi \quad$ : Parameter konstan

$\Theta_{q}$ : Parameter rataan bergerak (Moving Average)

$\varepsilon_{t} \quad$ : Nilai sisaan (error)

Model ARIMA (p,d,q) merupakan model umum dari regresi deret waktu sebab ARIMA $(p, 0,0)$ sama dengan AR $(p)$, ARIMA $(0,0, q)$ sama dengan MA (p) dan ARIMA $(p, 0, q)$ sama dengan ARMA (k,p).

\section{METODE PENELITIAN}

\section{Jenis dan Sumber Data}

Data yang digunakan untuk penulisan ini adalah data sekunder dari Januari 2008 saampai dengan Maret 2011 (data harian).
Data berupa nilai saham maksimum dan minimum PT. Telkom, Tbk yang diperoleh dari www.telkom.co.id/hubunganinvestor/informasi-saham/.

\section{Teknik Analisis Data}

Suatu model time series dikatakan baik apabila telah sesuai dengan kenyataan. Dengan kata lain, apabila kesalahan (error) model semakin kecil, maka model bisa dikatakan baik (Iriawan, 2006).

Analisis Data dilakukan menggunakan metode ARIMA dengan bantuan software statistika yaitu MINITAB 14. Langkahlangkah penerapan metode ARIMA secara berturut-turut adalah:

1. Pemeriksaan Kestasioneran Data

2. Identifikasi model dalam ARIMA. Melalui plot ACF dan PACF kita dapat menentukan model ARIMA yang bisa digunakan dalam prediksi.

3. Penentuan Parameter $\mathrm{p}, \mathrm{d}$ dan $\mathrm{q}$ dalam ARIMA.

4. Penentuan persamaan model ARIMA. Koefisien-koefisien yang digunakan dihasilkan dari hasil analisis parameter model ARIMA dengan MSE yang terkecil.

5. Validasi Prediksi.

6. Prediksi. Langkah selanjutnya adalah dengan menggunakan model terbaik untuk prediksi. Jika model terbaik telah ditetapkan, model itu siap digunakan untuk prediksi harga saham Telkom bulan Mei sampai Juni 2011

\section{HASIL DAN PEMBAHASAN}

Harga Saham Harian Maksimum PT. Telkom, Tbk Tahun 2009 sampai Maret 2011

Eksplorasi data harga saham harian maksimum PT. Telkom, Tbk dilakukan melalui plot deret waktu untuk periode 2009 sampai Maret 2011 selama 544 hari dapat dilihat pada gambar 1 . 


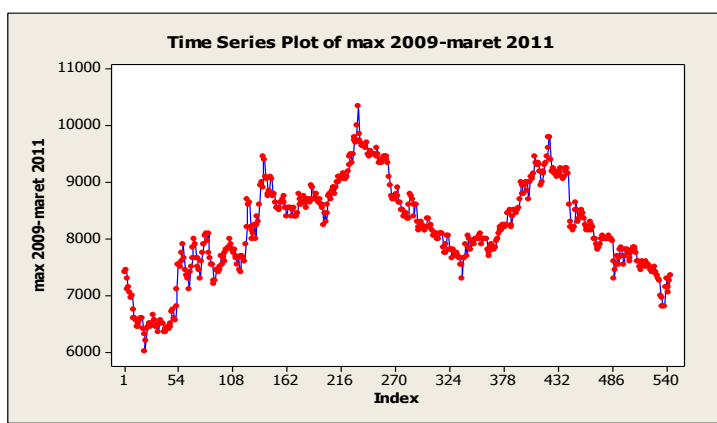

Gambar 1. Plot Data Harga Saham Harian Maksimum PT. Telkom, Tbk Tahun 2009 sampai Maret 2011

Pada gambar 1 terlihat harga saham diawali dengan Rp. 7.400 pada tanggal 5 Januari 2009 kemudian terjadi penurunan pada bulan Februari 2009 menjadi Rp. 6.000 tapi berangsur naik sampai Rp. 10.360 pada bulan Desember 2010 kemudian menurun dan naik kembali sampai akhirnya ditutup pada tanggal 31 Maret senilai Rp. 7.350. Dari gambar 1 juga bisa terlihat bahwa data belum stasioner karena masih mengalami perubahan seiring perubahan waktu.

Selain menggunakan plot data untuk mengetahui karakteristik data, plot data juga dapat diamati melalui koefisien Autocorrelation Function (ACF) dan Partial Autocorrelation Function (PACF) .

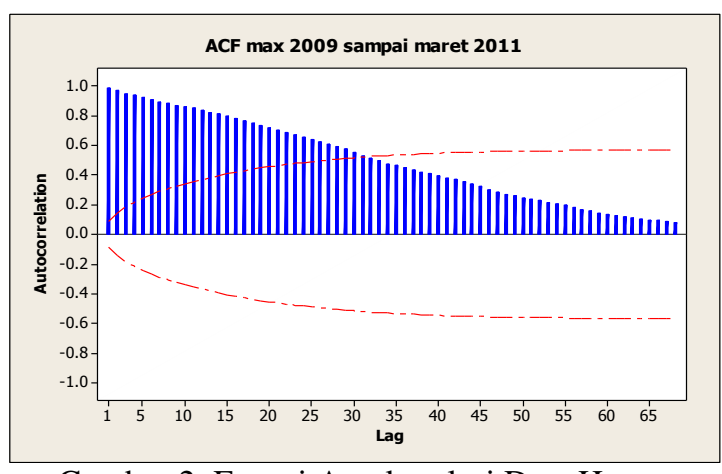

Gambar 2. Fungsi Autokorelasi Data Harga Saham Harian Maksimum PT. Telkom, Tbk Tahun 2009 sampai Maret 2011

Dari gambar 2 dan 3 dapat dilihat bahwa koefisien autokorelasi berbeda secara signifikan dari nol dan mengecil secara perlahan sedangkan semua koefisien autokorelasi parsial mendekati nol setelah lag pertama. Kedua hal tersebut menunjukkan bahwa data bersifat tidak stasioner khususnya tidak stasioner dalam rata-rata, padahal metode ARIMA memerlukan data yang bersifat stasioner. Karena itu perlu dilakukan metode pembedaan (Differencing). Hasilnya dapat dilihat dari gambar 4.

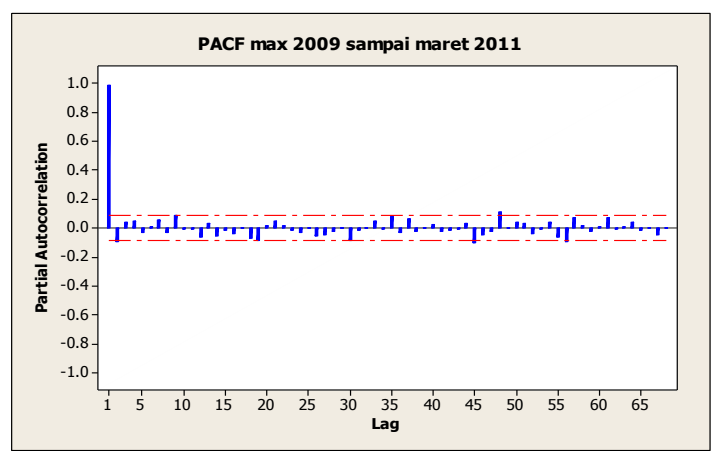

Gambar 3. Fungsi Autokorelasi Parsial Data Harga Saham Harian Maksimum PT. Telkom, Tbk Tahun 2009 sampai Maret 2011

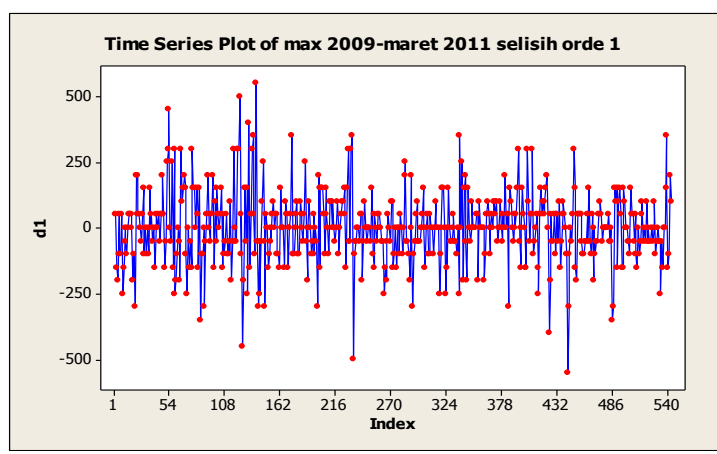

Gambar 4. Plot Data Harga Saham Harian Maksimum PT. Telkom, Tbk Tahun 2009 sampai Maret 2011 Selisih Orde 1

Pada gambar 4 data telah melalui proses pembedaan tingkat 1 . Dari data tersebut dapat diamati adanya data yang sudah bersifat stasioner. Proses pembedaan yang sudah dilakukan mengindikasikan bahwa nilai $\mathrm{d}$ yang bisa dipakai adalah nilai $\mathrm{d}=1$.

Setelah data sudah stasioner maka dilakukan plot untuk melihat model ARIMA yang akan digunakan. Dengan melihat plot ACF dan PACF seperti pada gambar 5 dan gambar 6.

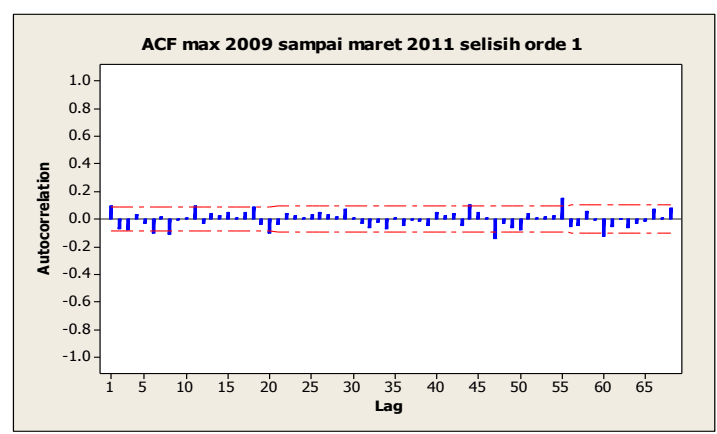

Gambar 5. Fungsi Autokorelasi Data Harga

Saham Harian Maksimum PT. Telkom, Tbk

Tahun 2009 sampai Maret 2011 Selisih Orde 1 


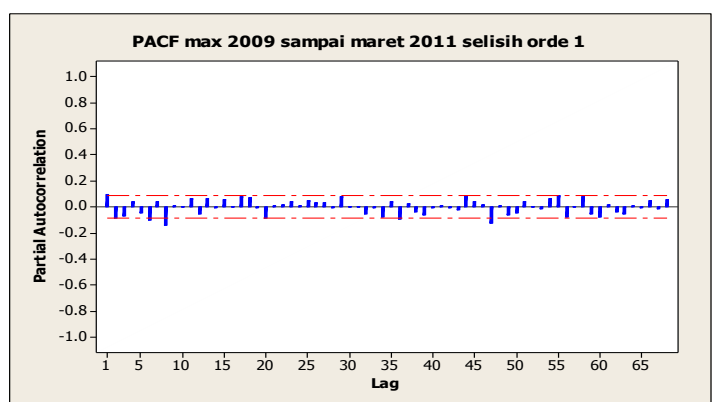

Gambar 6. Fungsi Autokorelasi Parsial Data

Harga Saham Harian Maksimum PT. Telkom,

Tbk Tahun 2009 sampai Maret 2011

Selisih Orde 1

Dari gambar 5 dan 6 dapat dilihat koefisien $\mathrm{ACF}$ dan PACF menurun secara eksponensial. Apabila ACF dan PACF turun secara eksponensial atau secara cepat maka hal ini menunjukkan bahwa model ARIMA yang bisa digunakan adalah model ARIMA $(\mathrm{p}, \mathrm{d}, \mathrm{q})$.

Untuk mengetahui nilai parameter ARIMA yang lebih terperinci dilakukan penentuan parameter $\mathrm{p}, \mathrm{d}$ dan $\mathrm{q}$. Tingkat akurasi prediksi dapat diukur melalui niali MSE (Mean Square Error) yang terkecil sehingga dapat diambil keputusan apabila suatu model layak digunakan.

Tabel 1. Penentuan Nilai p, d dan q dengan MSE untuk Data Harga Saham Harian Maksimum PT. Telkom, Tbk Tahun 2009 sampai Maret 2011

\begin{tabular}{|l|c|c|c|l|c|}
\hline \multicolumn{2}{|l|}{ Selisih 1 } & \multicolumn{2}{l|}{ Selisih 2 } & \multicolumn{2}{l|}{ Selisih 3 } \\
\hline $\begin{array}{l}\text { Param } \\
\text { eter }\end{array}$ & $\begin{array}{l}\text { Nilai } \\
\text { MSE }\end{array}$ & $\begin{array}{l}\text { Parame } \\
\text { ter }\end{array}$ & $\begin{array}{l}\text { Nilai } \\
\text { MSE }\end{array}$ & $\begin{array}{l}\text { Parame } \\
\text { ter }\end{array}$ & $\begin{array}{l}\text { Nilai } \\
\text { MSE }\end{array}$ \\
\hline$(0,1,0)$ & - & $(0,2,0)$ & - & $(0,3,0)$ & - \\
\hline$(1,1,0)$ & 18497 & $(1,2,0)$ & 29227 & $(1,3,0)$ & 59470 \\
\hline$(2,1,0)$ & 18401 & $(2,2,0)$ & 25635 & $(2,3,0)$ & 48263 \\
\hline$(3,1,0)$ & 18348 & $(3,2,0)$ & 23163 & $(3,3,0)$ & 39064 \\
\hline$(0,1,1)$ & 18472 & $(0,2,1)$ & - & $(0,3,1)$ & - \\
\hline$(1,1,1)$ & 18485 & $(1,2,1)$ & - & $(1,3,1)$ & - \\
\hline$(2,1,1)$ & - & $(2,2,1)$ & - & $(2,3,1)$ & - \\
\hline$(3,1,1)$ & 18349 & $(3,2,1)$ & - & $(3,3,1)$ & - \\
\hline$(0,1,2)$ & 18446 & $(0,2,2)$ & - & $(0,3,2)$ & - \\
\hline$(1,1,2)$ & 18325 & $(1,2,2)$ & - & $(1,3,2)$ & - \\
\hline$(2,1,2)$ & 18349 & $(2,2,2)$ & - & $(2,3,2)$ & - \\
\hline$(3,1,2)$ & 18196 & $(3,2,2)$ & 18395 & $(3,3,2)$ & - \\
\hline$(0,1,3)$ & 18273 & $(0,2,3)$ & - & $(0,3,3)$ & - \\
\hline$(1,1,3)$ & 18293 & $(1,2,3)$ & - & $(1,3,3)$ & - \\
\hline$(2,1,3)$ & 18335 & $(2,2,3)$ & - & $(2,3,3)$ & 31730 \\
\hline$(3,1,3)$ & 18123 & $(3,2,3)$ & 18360 & $(3,3,3)$ & - \\
\hline
\end{tabular}

Dari tabel 1 terdapat 48 model yang bisa digunakan untuk prediksi harga saham maksimum dengan data tahun 2009 sampai Maret 2011, berdasarkan teori semakin kecil nilai MSE yang dihasilkan maka model semakin baik. Nilai-nilai MSE yang tidak terisi menandakan parameter tersebut tidak dapat diestimasi oleh Minitab. Sehingga diketahui bahwa parameter $\mathrm{p}=3, \mathrm{~d}=1, \mathrm{q}=3$ atau ARIMA $(3,1,3)$ dengan nilai MSE yang terkecil yaitu 18123 dapat digunakan untuk memprediksi harga saham maksimum PT. Telkom, Tbk bulan Mei sampai Juni 2010.

\section{Menentukan Persamaan Model ARIMA $(p, d, q)$ pada Data Harga Saham Harian Maksimum PT. Telkom, Tbk Tahun 2009 sampai Maret 2011}

Dari hasil penentuan parameter diperoleh ARIMA (3,1,3) dengan koefisien-koefisen yaitu: AR 1:-0.0352, AR 2:-0.0219, AR 3:0.4443, MA 1: -0.1294, MA 2:0.0441, MA 3:0.5751 dan Konstanta: -0.006 (Lampiran 7). Dibuat analisis persamaan sebagai berikut untuk ARIMA $(3,1,3)$ menjadi :

$$
\begin{gathered}
\mathrm{Y}_{\mathrm{t}}=\mathrm{Y}_{\mathrm{t}-1}(1-0.0352)+\mathrm{Y}_{\mathrm{t}-2}(-0.0219+0.0352) \\
+\mathrm{Y}_{\mathrm{t}-3}(0.4443+0.0219)-0.4443 \mathrm{Y}_{\mathrm{t}-4}-0.006+ \\
0.1294 \varepsilon_{\mathrm{t}-1}-0.0441 \varepsilon_{\mathrm{t}-2}-0.5751 \varepsilon_{\mathrm{t}-3} \\
\mathrm{Y}_{\mathrm{t}}=0.9648 \mathrm{Y}_{\mathrm{t}-1}+0.0133 \mathrm{Y}_{\mathrm{t}-2}+0.4662 \mathrm{Y}_{\mathrm{t}-3} \\
-0.4443 \mathrm{Y}_{\mathrm{t}-4}-0.006+0.1294 \varepsilon_{\mathrm{t}-1}- \\
0.0441 \varepsilon_{\mathrm{t}-2}-0.5751 \varepsilon_{\mathrm{t}-3}
\end{gathered}
$$

Validasi Prediksi pada Data Harga Saham Harian Maksimum PT. Telkom, Tbk Tahun 2009 sampai Maret 2011

Validasi ini dilakukan agar bisa mengetahui kondisi data sebenarnya dengan hasil prediksi harga saham maksimum harian PT. Telkom, Tbk tahun 2009 sampai Maret 2011 menggunakan model ARIMA $(3,1,3)$. Dengan membandingkan hasil prediksi untuk bulan April tahun 2011 terhadap data sebenarnya sebelum digunakan untuk Mei sampai Juni didapatkan nilai MSE sebesar 8129.6314 dan nilai RMSE yaitu 90.16449. Interpretasi grafik dapat dilihat pada gambar 7:

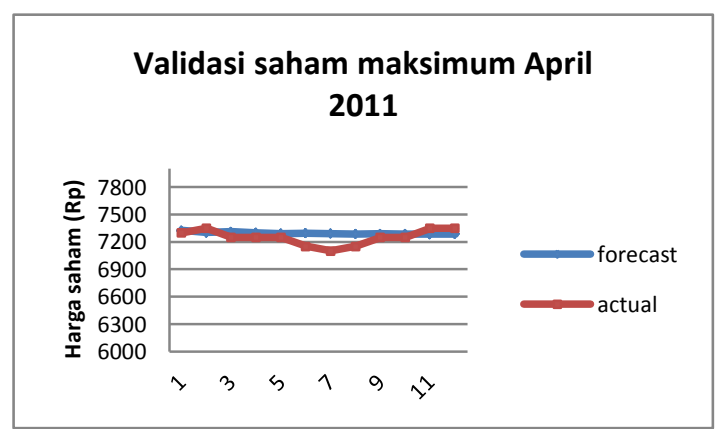

Gambar 7. Data Harga Saham Harian Maksimum Sebenarnya dan Prediksi PT.Telkom, Tbk April Tahun 2011 
Dari tampilan gambar 7 harga saham maksimum PT.Telkom April tahun 2011 tidak terlalu jauh berbeda dengan harga prediksi menggunakan ARIMA $(3,1,3)$. Oleh karena itu ARIMA $(3,1,3)$ bisa digunakan untuk memprediksi harga saham maksimum PT. Telkom, Tbk bulan Mei sampai Juni tahun 2011.

\section{Prediksi Data Harga Saham Harian Maksimum PT. Telkom, Tbk Bulan Mei sampai Juni Tahun 2011}

Dari tabel hasil perhitungan dan interpretasi grafik yang telah ada dapat diketahui bahwa hasil prediksi untuk harga saham maksimum PT. Telkom, Tbk bulan Mei sampai Juni tahun 2011 dapat dilakukan dengan menggunakan data harga saham harian tahun 2009 sampai Maret 2011, hasilnya seperti pada tabel 2 .

Tabel 2. Prediksi Harga Saham Harian Maksimum PT. Telkom, Tbk Bulan Mei sampai Juni Tahun 2011

\begin{tabular}{|c|c|c|c|}
\hline Mei & Prediksi & Juni & Prediksi \\
\hline $2 / 05 / 2011$ & 7282.9 & $01 / 06 / 2011$ & 7282.65 \\
\hline $3 / 05 / 2011$ & 7282.81 & $03 / 06 / 2011$ & 7282.64 \\
\hline $4 / 05 / 2011$ & 7282.87 & $06 / 06 / 2011$ & 7282.63 \\
\hline $5 / 05 / 2011$ & 7282.82 & $07 / 06 / 2011$ & 7282.62 \\
\hline $6 / 05 / 2011$ & 7282.78 & $08 / 06 / 2011$ & 7282.61 \\
\hline $9 / 05 / 2011$ & 7282.8 & $09 / 06 / 2011$ & 7282.6 \\
\hline $10 / 05 / 2011$ & 7282.77 & $10 / 06 / 2011$ & 7282.59 \\
\hline $11 / 05 / 2011$ & 7282.75 & $13 / 06 / 2011$ & 7282.58 \\
\hline $12 / 05 / 2011$ & 7282.75 & $14 / 06 / 2011$ & 7282.57 \\
\hline $13 / 05 / 2011$ & 7282.74 & $15 / 06 / 2011$ & 7282.56 \\
\hline $16 / 05 / 2011$ & 7282.72 & $16 / 06 / 2011$ & 7282.55 \\
\hline $18 / 05 / 2011$ & 7282.72 & $17 / 06 / 2011$ & 7282.54 \\
\hline $20 / 05 / 2011$ & 7282.7 & $20 / 06 / 2011$ & 7282.53 \\
\hline $23 / 05 / 2011$ & 7282.69 & $21 / 06 / 2011$ & 7282.52 \\
\hline $24 / 05 / 2011$ & 7282.69 & $22 / 06 / 2011$ & 7282.51 \\
\hline $25 / 05 / 2011$ & 7282.68 & $23 / 06 / 2011$ & 7282.5 \\
\hline $26 / 05 / 2011$ & 7282.66 & $24 / 06 / 2011$ & 7282.49 \\
\hline $27 / 05 / 2011$ & 7282.66 & $27 / 06 / 2011$ & 7282.48 \\
\hline & & $28 / 06 / 2011$ & 7282.47 \\
\hline & & $30 / 06 / 2011$ & 7282.46 \\
\hline
\end{tabular}

Harga Saham Harian Minimum PT. Telkom, Tbk Tahun 2009 sampai Maret 2011

Eksplorasi data harga saham harian minimum PT. Telkom, Tbk dilakukan melalui plot deret waktu untuk periode 2009 sampai Maret 2011 selama 544 hari dapat dilihat pada gambar 8 .

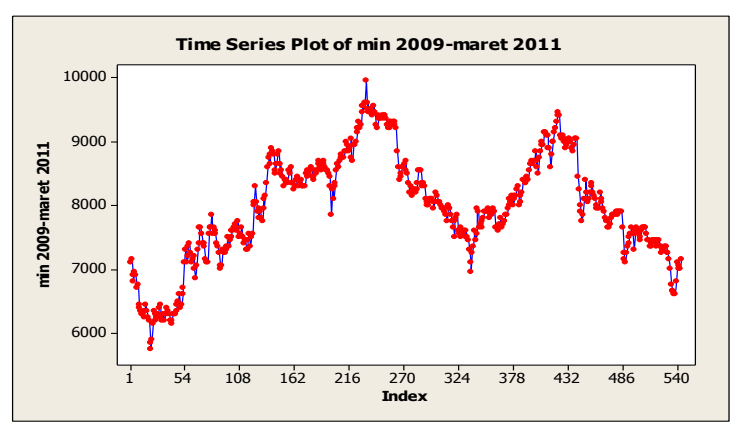

Gambar 8. Plot Data Harga Saham Harian Minimum PT. Telkom, Tbk Tahun 2009 sampai Maret 2011

Pada gambar 8 terlihat harga saham diawali dengan Rp. 7.100 pada tanggal 4 Januari 2009 dan kemudian terjadi penurunan pada bulan Februari 2009 yang mencapai Rp. 5.750 tapi berangsur naik sampai Rp.9.950 pada bulan Desember 2009 kemudian sempat menurun dan naik kembali sampai akhirnya ditutup pada tanggal 31 Maret 2011 sebesar Rp.7.150. Dari gambar 8 juga terlihat bahwa data belum stasioner hal ini karena data masih bergerak seiring perubahan waktu.

Proses selanjutnya adalah sama dengan data maksimum, yaitu plot ACF, PACF, pembedaan sehingga diperoleh parameter $p$, d, dan q.

Untuk mengetahui nilai parameter ARIMA yang lebih terperinci dilakukan penentuan parameter $p, d$ dan $q$. Penentuan $p$, d dan q dapat dilakukan melalui nilai MSE (Mean Square Error) yang terkecil.

Tabel 3. Penentuan Nilai p, d dan q dengan MSE untuk Data Harga Saham Harian Minimum PT.Telkom, Tbk Tahun 2009 sampai Maret 2011

\begin{tabular}{|c|c|c|c|c|c|}
\hline \multicolumn{2}{|c|}{ Selisih } & \multicolumn{2}{c|}{ Selisih } & \multicolumn{2}{c|}{ Selisih 3 } \\
\hline \multirow{2}{*}{ Parameter } & $\begin{array}{c}\text { Nilai } \\
\text { MSE }\end{array}$ & Parameter & $\begin{array}{c}\text { Nilai } \\
\text { MSE }\end{array}$ & Parameter & $\begin{array}{c}\text { Nilai } \\
\text { MSE }\end{array}$ \\
\hline$(0,1,0)$ & - & $(0,2,0)$ & - & $(0,3,0)$ & - \\
\hline$(1,1,0)$ & 17510 & $(1,2,0)$ & 25362 & $(1,3,0)$ & 53548 \\
\hline$(2,1,0)$ & 17521 & $(2,2,0)$ & 23804 & $(2,3,0)$ & 42824 \\
\hline$(3,1,0)$ & 17418 & $(3,2,0)$ & 22404 & $(3,3,0)$ & 37053 \\
\hline$(0,1,1)$ & 17512 & $(0,2,1)$ & - & $(0,3,1)$ & - \\
\hline$(1,1,1)$ & 17540 & $(1,2,1)$ & - & $(1,3,1)$ & - \\
\hline$(2,1,1)$ & 17513 & $(2,2,1)$ & - & $(2,3,1)$ & - \\
\hline$(3,1,1)$ & 17336 & $(3,2,1)$ & - & $(3,3,1)$ & 38905 \\
\hline$(0,1,2)$ & 17512 & $(0,2,2)$ & - & $(0,3,2)$ & - \\
\hline$(1,1,2)$ & 17499 & $(1,2,2)$ & - & $(1,3,2)$ & - \\
\hline$(2,1,2)$ & 17360 & $(2,2,2)$ & - & $(2,3,2)$ & - \\
\hline$(3,1,2)$ & 17390 & $(3,2,2)$ & - & $(3,3,2)$ & - \\
\hline$(0,1,3)$ & 17396 & $(0,2,3)$ & 19883 & $(0,3,3)$ & - \\
\hline$(1,1,3)$ & 17342 & $(1,2,3)$ & - & $(1,3,3)$ & - \\
\hline$(2,1,3)$ & 17368 & $(2,2,3)$ & - & $(2,3,3)$ & - \\
\hline$(3,1,3)$ & 17337 & $(3,2,3)$ & 17542 & $(3,3,3)$ & 23716 \\
\hline
\end{tabular}


Dari tabel 3 terdapat 48 model yang bisa digunakan untuk prediksi harga saham minimum dengan data tahun 2009 sampai Maret 2011, namun berdasarkan teori semakin kecil nilai MSE yang dihasilkan suatu model maka model semakin baik. Nilainilai MSE yang tidak terisi menandakan bahwa parameter tersebut tidak dapat diestimasi oleh Minitab. Sehingga dapat diketahui bahwa parameter $\mathrm{p}=3, \mathrm{~d}=1, \mathrm{q}=$ 1 atau ARIMA $(3,1,1)$ dengan nilai MSE yang terkecil yaitu 17336 dapat digunakan untuk memprediksi harga saham minimum PT. Telkom, Tbk bulan Mei sampai Juni tahun 2011.

Menentukan Persamaan Model ARIMA $(p, d, q)$ Pada Data Harga Saham Harian Minimum PT.Telkom, Tbk tahun 2009 sampai Maret 2011

Hasil penentuan parameter diperoleh ARIMA $(3,1,1)$ dengan koefisien-koefisien sebagai berikut yaitu: AR 1: 0.7504; AR 2: 0.0157; AR 3: -0.1077; MA 1: 0.7275; Konstanta: 0.051 (Lampiran 9) dibuat analisis persamaan untuk ARIMA $(3,1,1)$ menjadi:

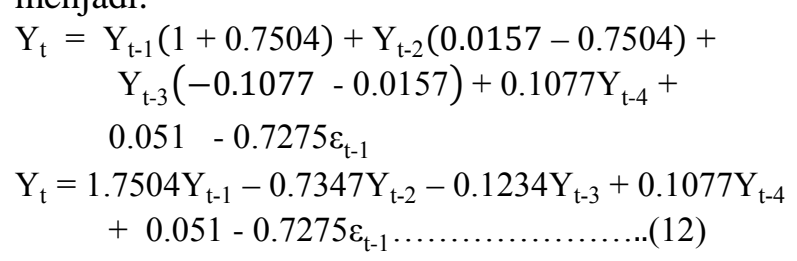

Validasi Prediksi pada Data Harga Saham Harian Minimum PT. Telkom, Tbk Tahun 2009 sampai Maret 2011

Validasi ini dilakukan agar mengetahui kondisi data sebenarnya dengan hasil prediksi harga saham maksimum harian PT. Telkom, Tbk tahun 2009 sampai Maret tahun 2011 menggunakan model ARIMA $(3,1,1)$. Dengan membandingkan hasil prediksi terhadap data aktual April tahun 2011, sebelum digunakan untuk Mei sampai Juni 2011 didapatkan nilai MSE yaitu 8310.124967 dan RMSE (Root Mean Square) senilai 91.15988683 .

Dari tampilan gambar 9, harga saham minimum PT. Telkom April 2011 tidak terlalu jauh berbeda dengan harga prediksi untuk April 2011 menggunakan ARIMA $(3,1,1)$. Oleh karena itu ARIMA $(3,1,1)$ bisa digunakan untuk memprediksi harga saham maksimum PT. Telkom, Tbk bulan Mei sampai Juni tahun 2011.

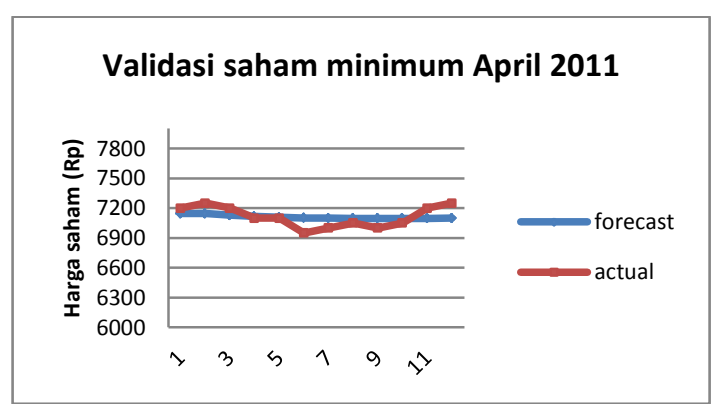

Gambar 9. Data Harga Saham Harian Minimum Sebenarnya dan Prediksi PT.Telkom, Tbk April Tahun 2011

\section{Prediksi Harga Saham Harian Minimum PT. Telkom, Tbk bulan Mei sampai Juni Tahun 2011}

Dari hasil perhitungan dan interpretasi grafik yang telah ada dapat diketahui bahwa, hasil prediksi untuk harga saham minimum PT. Telkom, Tbk tahun 2011 dapat dilakukan dengan menggunakan data harga saham harian tahun 2009 sampai Maret 2011. Hasil dari prediksi harga saham minimum PT. Telkom, Tbk bulan Mei sampai Juni dapat dilihat pada Tabel 4.

Tabel 4. Prediksi Harga Saham Minimum PT. Telkom, Tbk Bulan Mei sampai Juni Tahun 2011

\begin{tabular}{|c|c|c|c|}
\hline Mei & Prediksi & Juni & Prediksi \\
\hline $2 / 05 / 2011$ & 7099.65 & $01 / 06 / 2011$ & 7102.34 \\
\hline $3 / 05 / 2011$ & 7099.8 & $03 / 06 / 2011$ & 7102.49 \\
\hline $4 / 05 / 2011$ & 7099.94 & $06 / 06 / 2011$ & 7102.64 \\
\hline $5 / 05 / 2011$ & 7100.09 & $07 / 06 / 2011$ & 7102.79 \\
\hline $6 / 05 / 2011$ & 7100.24 & $08 / 06 / 2011$ & 7102.94 \\
\hline $9 / 05 / 2011$ & 7100.39 & $09 / 06 / 2011$ & 7103.09 \\
\hline $10 / 05 / 2011$ & 7100.54 & $10 / 06 / 2011$ & 7103.24 \\
\hline $11 / 05 / 2011$ & 7100.69 & $13 / 06 / 2011$ & 7103.39 \\
\hline $12 / 05 / 2011$ & 7100.84 & $14 / 06 / 2011$ & 7103.54 \\
\hline $13 / 05 / 2011$ & 7100.99 & $15 / 06 / 2011$ & 7103.68 \\
\hline $16 / 05 / 2011$ & 7101.14 & $16 / 06 / 2011$ & 7103.83 \\
\hline $18 / 05 / 2011$ & 7101.29 & $17 / 06 / 2011$ & 7103.98 \\
\hline $20 / 05 / 2011$ & 7101.44 & $20 / 06 / 2011$ & 7104.13 \\
\hline $23 / 05 / 2011$ & 7101.59 & $21 / 06 / 2011$ & 7104.28 \\
\hline $24 / 05 / 2011$ & 7101.74 & $22 / 06 / 2011$ & 7104.43 \\
\hline $25 / 05 / 2011$ & 7101.89 & $23 / 06 / 2011$ & 7104.58 \\
\hline $26 / 05 / 2011$ & 7102.04 & $24 / 06 / 2011$ & 7104.73 \\
\hline $27 / 05 / 2011$ & 7102.19 & $27 / 06 / 2011$ & 7104.88 \\
\hline & & $28 / 06 / 2011$ & 7105.03 \\
\hline & & $30 / 06 / 2011$ & 7105.18 \\
\hline
\end{tabular}




\section{KESIMPULAN}

Model untuk harga saham maksimum adalah ARIMA $(3,1,3)$ dengan persamaan: $\mathrm{Y}_{\mathrm{t}}=0.9648 \mathrm{Y}_{\mathrm{t}-1}+0.0133 \mathrm{Y}_{\mathrm{t}-2}+0.4662 \mathrm{Y}_{\mathrm{t}-3}$ $-0.4443 \mathrm{Y}_{\mathrm{t}-4}-0.006+0.1294 \varepsilon_{\mathrm{t}-1}-$ $0.0441 \varepsilon_{\mathrm{t}-2}-0.5751 \varepsilon_{\mathrm{t}-3}$. Sedangkan harga saham minimum adalah ARIMA $(3,1,1)$ dengan persamaan:

$\mathrm{Y}_{\mathrm{t}}=1.7504 \mathrm{Y}_{\mathrm{t}-1}-0.7347 \mathrm{Y}_{\mathrm{t}-2}-0.092 \mathrm{Y}_{\mathrm{t}-3}$ $+0.1077 Y_{t-4}+0.051-0.7275 \varepsilon_{t-1}$.

Prediksi harga saham maksimum dan minimum PT. Telkom, Tbk untuk bulan Mei sampai Juni didapatkan harga saham berkisar antara Rp. 7.099 sampai Rp. 7.282

\section{DAFTAR PUSTAKA}

Anonim. 2010. Harga saham PT.Telkom, Tbk. (www.telkom.co.id/hubunganinvestor/informasi saham, oktober 2010 - April 2011).

Anonim. 2010. Profil Perusahaan PT. Telkom (http://www.telkom.co.id/info-perusahaan/index.html\#telkom, Oktober 2010).
Assauri, S. 1984. Teknik dan Metode Peramalan. Penerapannya Dalam Ekonomi dan Dunia Usaha Edisi Satu. LP Fakultas Ekonomi UI. Jakarta.

Halim. 2006. Diktat Time Series. Universitas Kristen Petra. Surabaya.

Iriawan, N dan P.S. Astuti. 2006. Mengolah Data Statistik Dengan Mudah Menggunakan Minitab 14. Penerbit Andi. Yogyakarta.

Mulyana. 2004. Buku Ajar Analisis Deret Waktu. Universitas Padjajaran FMIPA Jurusan Statistika. Bandung

Razak. Abd. Fadhilah. 2009. Load Forecasting Using Time Series Models. Jurnal Kejuruteraan. 21: 53-62

Sadeq. A. 2008. Analisis Prediksi Indeks Harga Saham Gabungan dengan Metode ARIMA [Tesis]. Pasca Sarjana UNDIP. Semarang

Sartono, B. 2006. Modul Kuliah Pelatihan Time Series Analysis. IPB. Bogor 